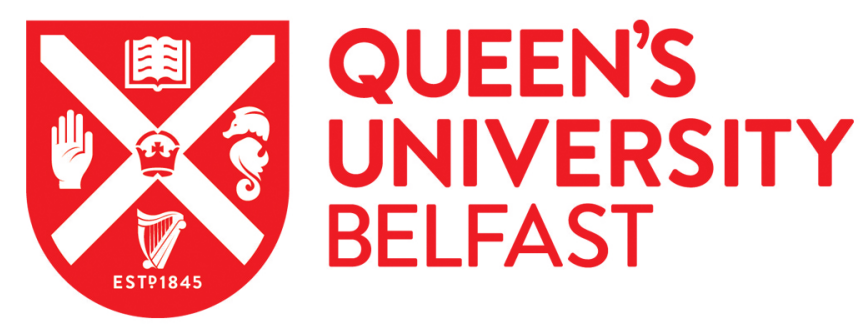

\title{
Hill Climbing Maximum Power Point Tracking on Four Stage Switch Capacitor Based Boost Converter
}

Rahim, N. A., Amir, A., Che, H. S., \& Elkhateb, A. (2019). Hill Climbing Maximum Power Point Tracking on Four Stage Switch Capacitor Based Boost Converter. In 5th IET International Conference on Clean Energy and Technology (CEAT 2018) Institute of Electrical and Electronics Engineers Inc.. https://doi.org/10.1049/cp.2018.1360

Published in:

5th IET International Conference on Clean Energy and Technology (CEAT 2018)

Document Version:

Peer reviewed version

Queen's University Belfast - Research Portal:

Link to publication record in Queen's University Belfast Research Portal

Publisher rights

Copyright 2018 IEEE. This work is made available online in accordance with the publisher's policies. Please refer to any applicable terms of use of the publisher.

\section{General rights}

Copyright for the publications made accessible via the Queen's University Belfast Research Portal is retained by the author(s) and / or other copyright owners and it is a condition of accessing these publications that users recognise and abide by the legal requirements associated with these rights.

Take down policy

The Research Portal is Queen's institutional repository that provides access to Queen's research output. Every effort has been made to ensure that content in the Research Portal does not infringe any person's rights, or applicable UK laws. If you discover content in the Research Portal that you believe breaches copyright or violates any law, please contact openaccess@qub.ac.uk. 


\title{
HILL CLIMBING MAXIMUM POWER POINT TRACKING ON FOUR STAGE SWITCH CAPACITOR BASED BOOST CONVERTER
}

\author{
Nasrudin Abd Rahim, Asim Amir, Aamir Amir, Hang Seng Che, Ahmad ElKhateb \\ UM Power Energy Dedicated Advanced Centre (UMPEDAC) \\ Level 4, Wisma RnD, University of Malaya, Jalan Pantai Baharu, 59990, Kuala Lumpur, Malaysia
}

\begin{abstract}
In this paper, a theoretical analysis has been presented to observe the performance of the Hill Climbing (HC) Maximum Power Point Tracking (MPPT) technique on the Four Stage Switch Capacitor Based Boost Converter (4-SCBC). To implement the $\mathrm{HC}$, a 4-SCBC is connected with a resistive load. In addition, a KC85T Solar Module has been employed to witness the operational performance of the 4-SCBC to realize a Stand-Alone Photovoltaic (PV) system, while operating near MPP, at the left of MPP (LM) or at the right of MPP (RM). In order to attain software simulation results, the MATLAB Simulink was employed. Results obtained prove to be parallel in performance with the theoretical analysis presented.
\end{abstract}

Index Terms-Four stage switch capacitor, boost converter, maximum power point (MPP) tracking (DMPPT), standalone PV system.

\section{INTRODUCTION}

Amidst the global efforts to reduce reliance on fossil-based energy in the past few decades, solar photovoltaic (PV) energy has emerged as one of the most promising renewable energy sources due to its reliability and cleanliness [1-4]. However, high installation expenses, dependency on weather condition and low-efficiency, remain the main drawbacks of solar PV. To increase the energy yield and increase the return on investment, various maximum power point tracking (MPPT) techniques have been proposed to ensure the PV panel can operate around the maximum power point (MPP) [5]. In [6], a review of different MPPT techniques based on analog and digital approach was presented. Apart from HVT and inductor based converters, some non-isolated converters achieve high gains based on switched capacitor (SC) technique, which can be found under categories such as voltage-lift $[7,8]$, three-switch high voltage [9-11] and voltage multiplier [12]. In [13], a family of SC-based high voltage gain converters was proposed where the authors demonstrated the principles of achieving boost and buck-boost operation by configuring the position of the SC cells. However, the topologies are not extendable and are only restricted to two stages of SC cell, with limited voltage gain. In [14], the authors attempted to improve the work in [13] by introducing switched inductor (SI) cells, such that the voltage boosting stages can be extended for higher voltage gain.

In this paper, Section 2 presents the mathematical modelling of the PV solar cell. Section 3 introduces the Four-Stage Switch Capacitor Based Boost converter utilized and the PV module employed. Section 4 presents an overview of the Hill Climbing technique under consideration. Section 5 provides the theoretical analysis for the operational performance of the $\mathrm{HC}$ technique on a Stand-Alone PV system utilizing a 4-SCBC. Simulation results of the proposed 4-SCBC with $\mathrm{HC}$ is presented in Section 6. Lastly, conclusion of this work is offered in Section 7.

\section{PV MODEL}

The output power of the PV cell is dependent on environmental variations by temperature and irradiation. Therefore, the PV cell is considered a non-linear DC current source. An ideal PV cell equivalent circuit model has been presented in Fig. 1.

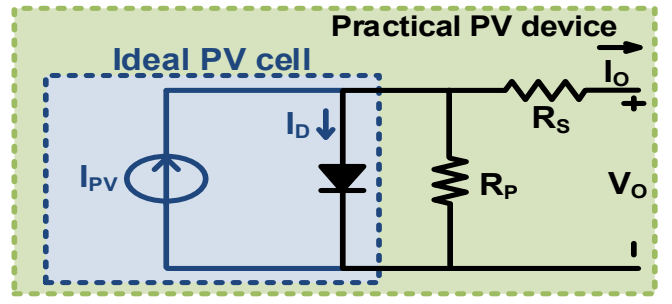

Fig. 1. Ideal PV cell equivalent circuit [15].

The mathematical and theoretical modelling of an ideal PV cell can be evaluated as presented in [16] as:

$I=I_{p v}-I_{0}\left[\exp \left(\frac{V-R_{S} I}{V_{t} a}\right)-1\right]-\frac{V+R_{S} I}{R_{p}}$ 
Here, $V_{t}=\frac{N_{s} k T}{q}$ remains thermal voltage, $I_{p v}$ current produced by incident light, $N \mathrm{~s}$ cells in series and $I_{0}$ reverse saturation current. The PV cell output remains predictable as signified by equation (1). Where, irradiance and temperature remains the important parameters affecting the PV cell output. Figs. 2(a, b) and Fig. 3(a, b) show such variations.

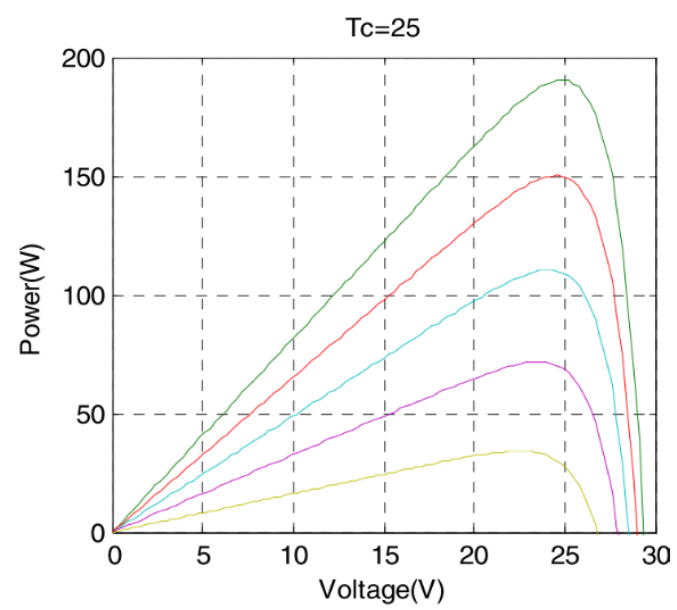

Fig. 2 (a). Under changing irradiance and constant temperature at $\mathrm{Tc}=25^{\circ} \mathrm{C}[17]$.

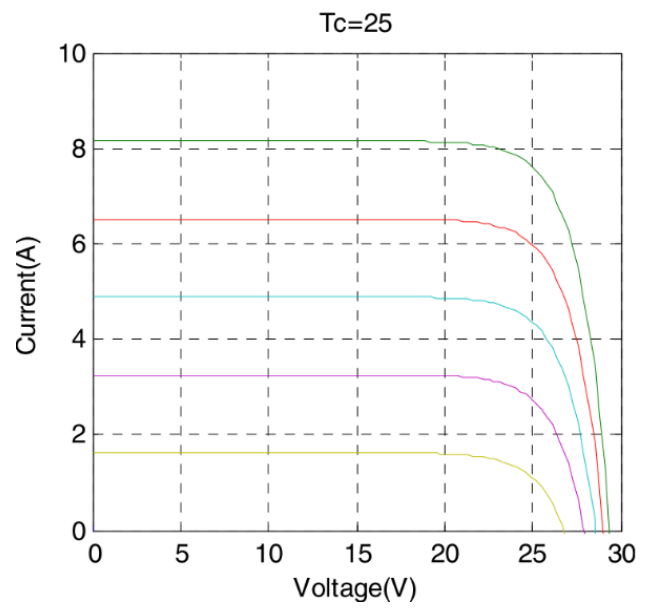

Fig. 2 (b). Under changing irradiance and constant temperature at $\mathrm{Tc}=25^{\circ} \mathrm{C}[17]$.

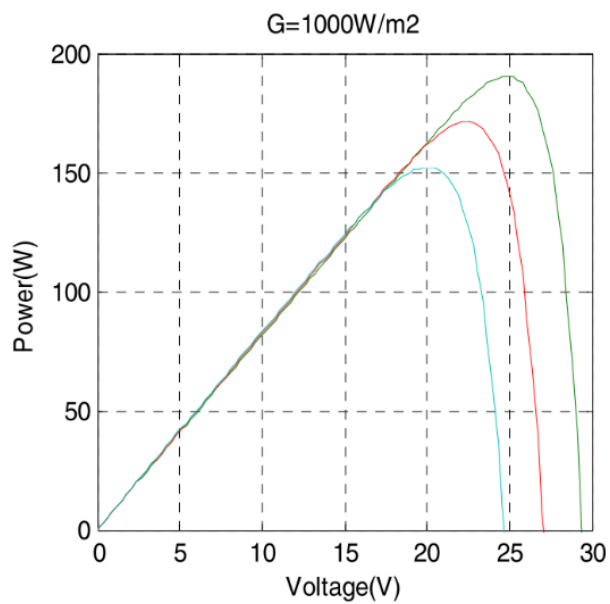

Fig. 3 (a). Under constant irradiance at $1000 \mathrm{~W} / \mathrm{m}^{2}$ and changing temperature [17].

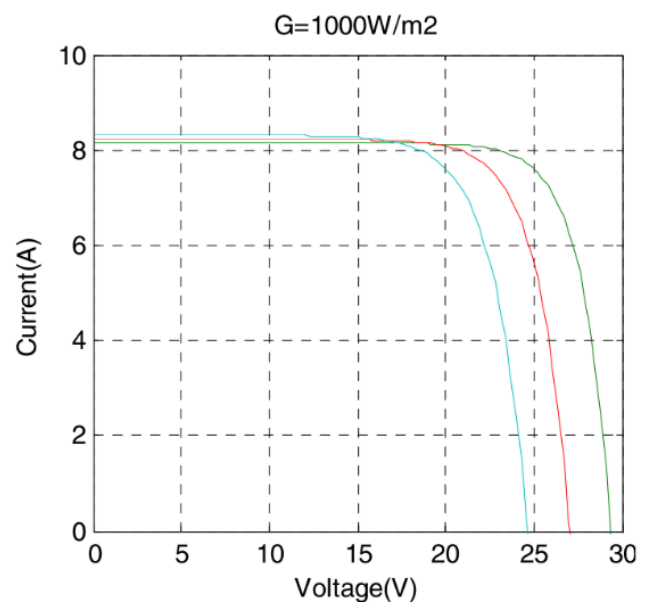

Fig. 3 (b). Under constant irradiance at $1000 \mathrm{~W} / \mathrm{m}^{2}$ and changing temperature [17].

In order to assess the optimum performance of the proposed technique such variations have been taken into consideration.

\section{4-SCB CONVERTER}

Fig. 4 presents the design configuration of the 4-SCBC. System parameters of the 4-SCBC are shown in Table I. The $\mathrm{SC}$ based converters for stand-alone PV system application can utilize Maximum Power Point Tracking (MPPT) techniques. An analog and digital classification of such techniques has been presented in [6]. In particular, MPPT techniques as the conventional and modified techniques presented in [18], optimization techniques as Ant Colony Optimization [19], and 
BAT search algorithm can also be applied with an SC-based converter for MPPT tracking. This paper demonstrates that by modifying the SC cells, a simple extendable SC-based converter can be obtained based on the topology in [13] without using inductors.

TABLE I

SYSTEM PARAMETERS FOR 4-SCBC

\begin{tabular}{cc}
\hline \hline System Parameters & 4-SCBC (Resistive \\
& Load) \\
\hline Switching Frequency (SF) & $20 \mathrm{kHz}$ \\
Sampling Time (ST) & $0.1 \mathrm{~s}$ \\
Input Capacitance (Ci) & $2200 \mu \mathrm{F}$ \\
$L$ & $560 \mu \mathrm{H}$ \\
$C_{o}$ & $220 \mu \mathrm{F}$ \\
Load & $15 \Omega$ \\
Switch Capacitor & $1 \mu \mathrm{F}$
\end{tabular}

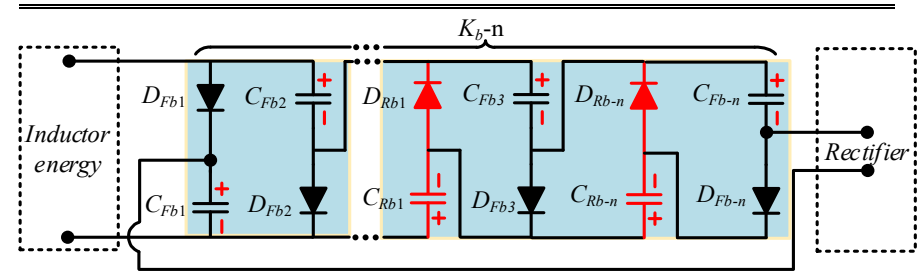

(a)

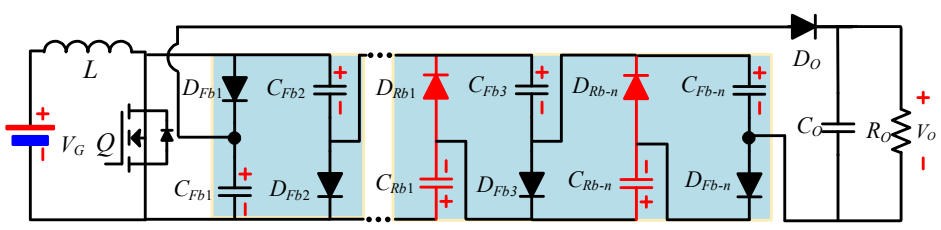

(b)

Fig. 4. (a) SC cell (b) N-stage Boost SC Converter with resistive load.

Table 2 presented the electrical performance parameters of the PV module utilized in order to assess the performance of the proposed MPPT technique.

TABLE II

PVMODULE

\begin{tabular}{cc}
\hline \hline Parameters & Value \\
\hline Maximum PV Power (Pmpp) & $87 \mathrm{~W}$ \\
Voltage at MPP (Vmpp) & $17.4 \mathrm{~V}$ \\
Current at MPP (Impp) & $5.02 \mathrm{~A}$ \\
Open Circuit Voltage (Voc) & $21.7 \mathrm{~V}$ \\
Short Circuit Current (Isc) & $5.34 \mathrm{~A}$ \\
Series cells & 36 \\
\end{tabular}

Analysis on the boost and buck-boost modes of operation is presented, and the impact on efficiency and gain, as the number of SC stage increases, are discussed.

\section{HC METHOD}

The HC technique has been presented in [6, 20-22], the principle operation of the $\mathrm{HC}$ technique is duty cycle dependent. For the direct implementation, change of power is considered as the primary value for the required duty cycle change. Flowchart of the $\mathrm{HC}$ technique has been presented in Fig. 5.

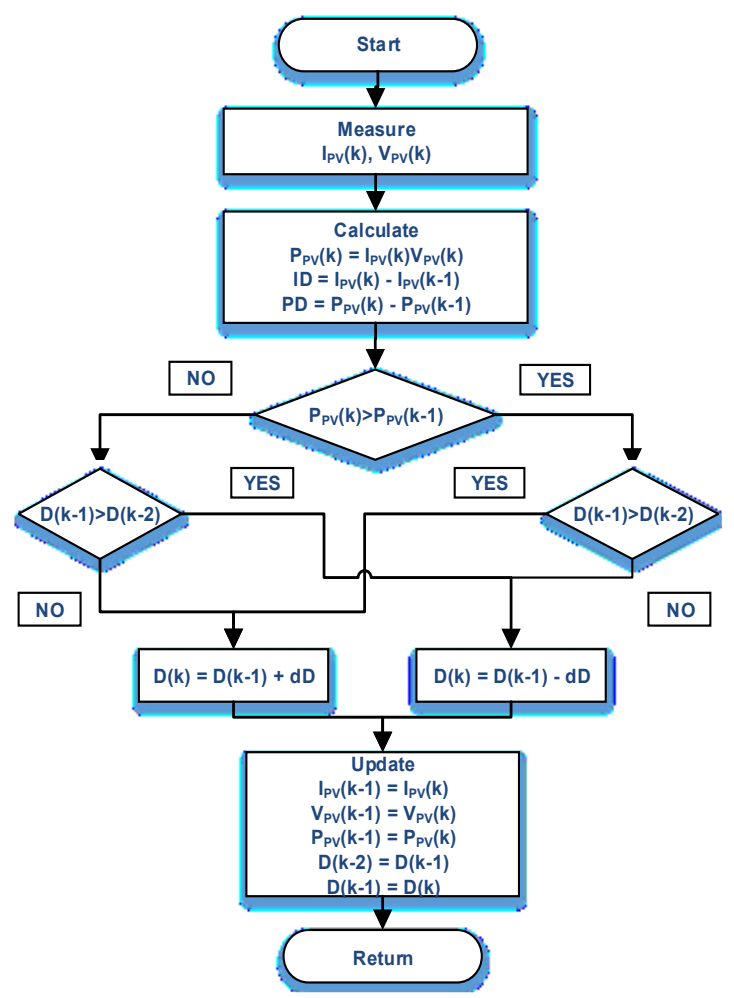

Fig. 5. Flowchart for the Hill Climbing Technique.

\section{HC FOR MPPT ON 4-SCBC}

The CA provides a combined approach for the $\mathrm{HC}$ and the FPM. This amalgamation has several advantages as it offers the precise close bracket limits, restricted operational range, and remains independent of the PV array. These merits have been highlighted as follows:

\section{A. For High D}


In some applications where high gain is required, modifications to the Boost converter is necessary. One such modified highgain boost converter is the 2-Stage Switched Capacitor (2-SSC) Boost converter as shown in Fig. 4.

Similar to the conventional Boost converter, the effective resistance for 2-SSC converter can be expressed as,

$R_{p v}=\frac{V_{p v}}{I_{p v}}=\frac{R(1-D)^{2}}{16}$

Convergence rate of $V_{p v}$ can be attained as

$\frac{\Delta V_{p v}}{\Delta D}=\frac{(D-1)}{8} k$

Similarly, as observed from equation (3), the change in voltage for 2-SSC Boost is directly proportional with duty cycle. However, the change in voltage will be less than that observed with conventional boost converter.

\section{B. At $M P P$}

Similarly, for 2-SSC the change in voltage with respected to D, closer to MPP can be realized as,

$\frac{\Delta V_{p v}}{\Delta D}=\frac{(D-1) V_{M P P}}{(1-D)^{2}}$

\section{For Low D}

Similarly, for 2-SSC the change in voltage with respected to D, away from MPP at low D can be realized as,

$\frac{\Delta V_{p v}}{\Delta D}=\frac{R}{16}\left(\frac{\Delta I_{p v}}{\Delta D}(1-D)^{2}\right)+\frac{16(2 D-2) V_{p v}}{(1-D)^{2}}$

From equations (3) and (5), the directions of input voltage and the Duty cycle remain the same, so the change in voltage is essentially positive and higher than the conventional boost converter.

\section{Simulation Results}

Matlab Simulink software has been utilized in the research work to validate the optimum performance of the proposed method for MPPT. As discussed earlier the CA has been evaluated on the environmentally changing conditions. As observed in Fig. 6. (a) From time $0 \mathrm{~s}$ to $1 \mathrm{~s}$ the results are obtained under STC. Further, the irradiance changes from 1000 $\mathrm{W} / \mathrm{m}^{2}$ to $700 \mathrm{~W} / \mathrm{m}^{2}$ at time $1 \mathrm{~s}$. Finally, the irradiance is set back to $1000 \mathrm{~W} / \mathrm{m}^{2}$ at time $2 \mathrm{~s}$. Duty cycle change is presented in black colored plot, PV voltage in blue, PV input current in red and $\mathrm{PV}$ power change for the $\mathrm{BC}$ in green. As observed in Fig. 6. (b), which is a zoom-in version of the previous plots under STC. The CA with FPM takes almost 6 steps to attain the MPP.
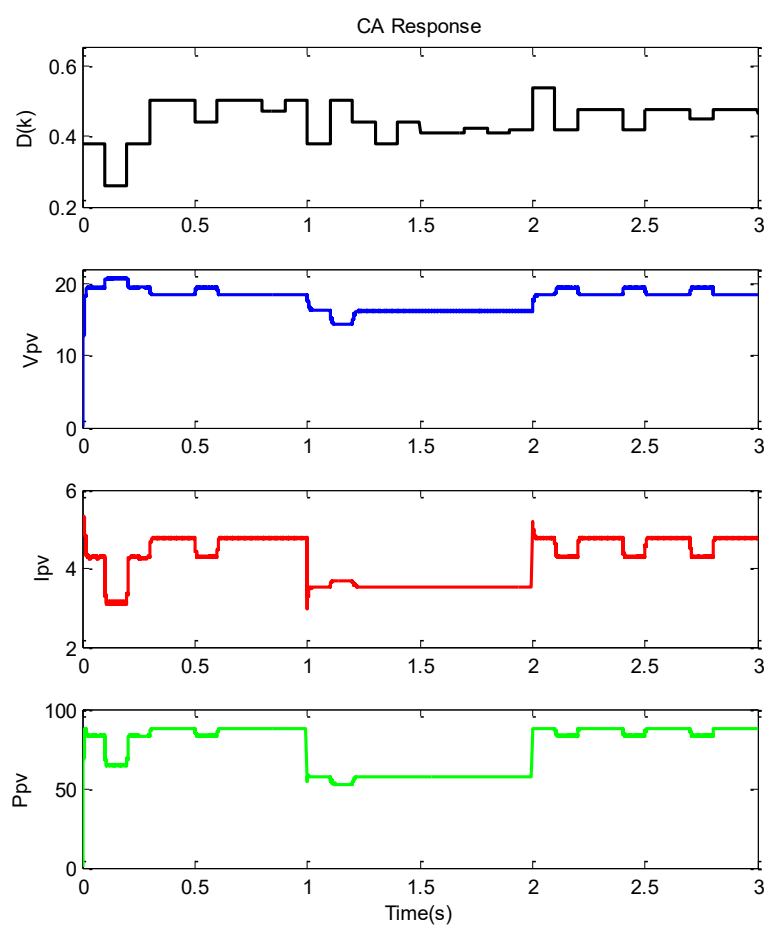

(a)
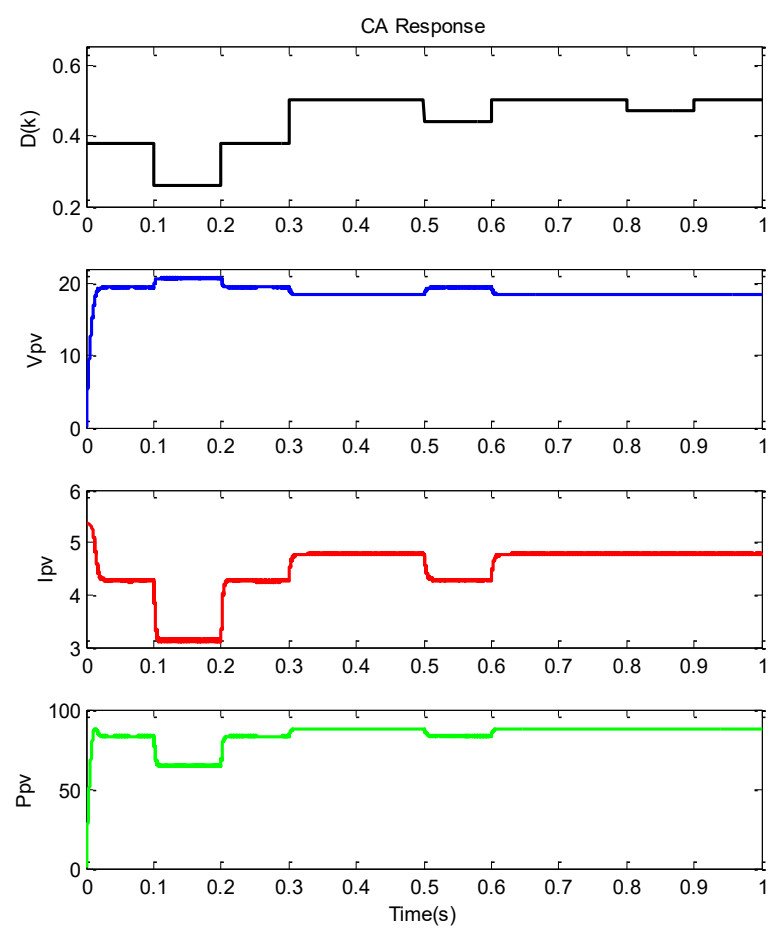

(b)

Fig. 6. FPM to track the MPP. 
This proves that the CA under steady state operation offers a better performance than $\mathrm{HC}$ by eliminating the oscillation around the MPP. Further, during a change in irradiance the FPM settles in almost 3 steps for $700 \mathrm{~W} / \mathrm{m}^{2}$ irradiance. Moreover, the operation back to $1000 \mathrm{~W} / \mathrm{m}^{2}$ also requires 6 steps to attain the MPP. Therefore, for the CA, the HC under the constant current region is utilized to predict the close bracket limits, making the technique PV array independent, offers a wide range of operation, offer a real-time performance and above all the CA remains simple to implement.

\section{CONCLUSION}

The HT offers an improved performance for DMPPT. As, the HT, due to its combination of MINC and MCNM, attains reliability, accuracy and speed. Moreover, the application of DMPPT on Buck, Boost, OBC and 2-SSC converter topologies has been theoretically analyzed to ascertain the optimum performance of DMPPT for such converters. The shortcomings of CNM have also been addressed, as the HT is PV array independent, determines the range of operation based on real weather conditions and remains accurate in determining the initial guesses so that the numerical methods can operate accurately. Simulation and experimental results present a quite evident picture that the HT offers an improved performance for MPPT. It offers a moderated approach between the conventional MPPT techniques and the numerical methods. It is convenient because of the convergence at the MPP and the faster response as compared to the MINC.

\section{ACKNOWLEDGEMENT}

The authors would like to thank the financial and technical assistance provided by the University of Malaya and UM Power Energy Dedicated Advanced Centre (UMPEDAC). As well as Mohe HiCoe - the High Impact Research Grant (H-16001-00D000032), Fundamental Research Grant Scheme FP0652014A, the project funding from the Malaysian Ministry of Higher Education undergrant MO013-2016 (Investigation on The Next Generation Renewable Energy Generators Based on M.O.R.E Intelligent Power Electronics Converters) and Postgraduate Research Fund (PPP) Project Number: PG029$2015 B$.

\section{REFERENCES}

1 Fathabadi, H.: 'Novel standalone hybrid solar/wind/fuel cell/battery power generation system', Energy, 2017, 140, pp. 454-465

2 Luo, Y., Zhang, L., Liu, Z., Wu, J., Zhang, Y., and $\mathrm{Wu}, \mathrm{Z}$. .: 'Numerical evaluation on energy saving potential of a solar photovoltaic thermoelectric radiant wall system in cooling dominant climates', Energy, 2018, 142, pp. 384-399

3 Leonard, M.D., and Michaelides, E.E.: 'Gridindependent residential buildings with renewable energy sources', Energy, 2018, 148, pp. 448-460

4 Amir, A., Che, H.S., Amir, A., El Khateb, A., and Rahim, N.A.: 'Transformerless high gain boost and buck-boost DC-DC converters based on extendable switched capacitor (SC) cell for stand-alone photovoltaic system', Solar Energy, 2018, 171, pp. 212-222

5 Boukenoui, R., Ghanes, M., Barbot, J.P., Bradai, R., Mellit, A., and Salhi, H.: 'Experimental assessment of Maximum Power Point Tracking methods for photovoltaic systems', Energy, 2017, 132, pp. 324-340

6 Amir, A., Amir, A., Selvaraj, J., and Rahim, N.A.: 'Study of the MPP tracking algorithms: Focusing the numerical method techniques', Renewable and Sustainable Energy Reviews, 2016, 62, pp. 350-371

7 Luo, F.L.: 'Six self-lift DC-DC converters, voltage lift technique', IEEE Transactions on Industrial Electronics, 2001, 48, (6), pp. 1268-1272

8 Luo, F.L., and Ye, H.: 'Positive output multiple-lift push-pull switched-capacitor Luo-converters', IEEE transactions on industrial electronics, 2004, 51, (3), pp. 594602

9 Zhou, D., Pietkiewicz, A., and Cuk, S.: 'A threeswitch high-voltage converter', IEEE Transactions on Power Electronics, 1999, 14, (1), pp. 177-183

10 Yang, L.-S., Liang, T.-J., and Chen, J.-F.: 'Transformerless DC-DC converters with high step-up voltage gain', IEEE Transactions on Industrial Electronics, 2009, 56, (8), pp. 3144-3152

11 Axelrod, B., Berkovich, Y., and Ioinovici, A.: 'Transformerless DC-DC converters with a very high DC lineto-load voltage ratio', in Editor (Ed.) $)^{\wedge}$ Eds.): 'Book Transformerless DC-DC converters with a very high DC lineto-load voltage ratio' (IEEE, 2003, edn.), pp. 435-438

12 Baek, J.-W., Ryoo, M.-H., Kim, T.-J., Yoo, D.-W., and Kim, J.-S.: 'High boost converter using voltage multiplier', in Editor (Ed.) $)^{\wedge}$ Eds.): 'Book High boost converter using voltage multiplier' (IEEE, 2005, edn.), pp. 567-572

13 Ismail, E.H., Al-Saffar, M.A., Sabzali, A.J., and Fardoun, A.A.: 'A family of single-switch PWM converters with high step-up conversion ratio', IEEE Transactions on Circuits and Systems I: Regular Papers, 2008, 55, (4), pp. 11591171

14 Wu, G., Ruan, X., and Ye, Z.: 'Nonisolated high stepup DC-DC converters adopting switched-capacitor cell', IEEE 
Transactions on Industrial Electronics, 2015, 62, (1), pp. 383 393

15 Rauschenbach, H.: 'Solar Cells Array Design Handbook: The Principles and Technology of Photovoltaic Energy Conversion' (Van Nostrand Reinhold, 1980. 1980)

16 Villalva, M.G., and Gazoli, J.R.: 'Comprehensive approach to modeling and simulation of photovoltaic arrays', Power Electronics, IEEE Transactions on, 2009, 24, (5), pp. 1198-1208

17 Nianchun, W., MeiYue, W., and GuoSHeng, S.: 'Study on characteristics of photovoltaic cells based on MATLAB simulation', in Editor (Ed.)^(Eds.): 'Book Study on characteristics of photovoltaic cells based on MATLAB simulation' (IEEE, 2011, edn.), pp. 1-4

18 Amir, A., Amir, A., Selvaraj, J., Rahim, N.A., and Abusorrah, A.M.: 'Conventional and modified MPPT techniques with direct control and dual scaled adaptive stepsize', Solar Energy, 2017, 157, pp. 1017-1031
19 Oshaba, A., Ali, E., and Elazim, S.A.: 'ACO based speed control of SRM fed by photovoltaic system', International Journal of Electrical Power \& Energy Systems, 2015,67 , pp. $529-536$

20 Alajmi, B.N., Ahmed, K.H., Finney, S.J., and Williams, B.W.: 'Fuzzy-logic-control approach of a modified hill-climbing method for maximum power point in microgrid standalone photovoltaic system', IEEE Transactions on Power Electronics, 2011, 26, (4), pp. 1022-1030

21 Xiao, W., and Dunford, W.G.: 'A modified adaptive hill climbing MPPT method for photovoltaic power systems', in Editor (Ed.) ${ }^{\wedge}$ (Eds.): 'Book A modified adaptive hill climbing MPPT method for photovoltaic power systems' (Ieee, 2004, edn.), pp. 1957-1963

22 Esram, T., and Chapman, P.L.: 'Comparison of photovoltaic array maximum power point tracking techniques', IEEE Transactions on energy conversion, 2007, 22, (2), pp. 439-449 